\title{
Clinical Management of Ocular Surface Squamous Neoplasia: A Review of the Current Evidence
}

\author{
Maria Vittoria Cicinelli · Alessandro Marchese · Francesco Bandello • \\ Giulio Modorati
}

Received: June 12, 2018 / Published online: July 20, 2018

(C) The Author(s) 2018

\begin{abstract}
Ocular surface squamous neoplasia (OSSN) is the most common non-pigmented malignancy of the ocular surface and is represented in a wide range of histologic diagnoses, ranging from mild epithelial dysplasia to invasive squamous carcinoma. Although surgical excision is still the gold standard for OSSN treatment, interest in conservative medical approaches is steadily growing. We have reviewed all of the literature on OSSN published in English in the MEDLINE database up to May 2018, using the keywords "ocular surface squamous neoplasia," "squamous conjunctival carcinoma," and "conjunctival carcinoma in situ," with the aim to provide a comprehensive review of the most recent evidence on this distinct clinical entity.
\end{abstract}

Enhanced digital features To view enhanced digital features for this article go to https://doi.org/10.6084/ m9.figshare.6803627.

M. V. Cicinelli $(\bowtie) \cdot$ A. Marchese · F. Bandello .

G. Modorati

Oncology Unit, Department of Ophthalmology,

University Vita-Salute-IRCCS Ospedale San Raffaele,

Milan, Italy

e-mail: cicinelli.mariavittoria@hsr.it
Keywords: Conjunctival carcinoma; Ocular surface squamous neoplasia; Squamous conjunctival carcinoma

\section{INTRODUCTION}

First proposed in 1995 as a distinct clinical entity [1], ocular surface squamous neoplasia (OSSN) is an umbrella term which includes a broad spectrum of conjunctival malignancies, ranging from mild epithelial dysplasia to invasive squamous carcinoma (SCC) [2]. It is the most common non-pigmented malignancy of the ocular surface [3], with an incidence that ranges from $0.03-1.9$ per $100,000 /$ year in the Caucasian population [4-7], to 3-3.4 per $100,000 /$ year in African ethnicity populations $[8,9]$.

Surgical excision is still the gold standard of treatment; however, due to the high rate of recurrence of the tumor, interest in conservative medical approaches has been progressively increasing in recent years [10]. The aim of this review was to report the most recent evidence on this entity, focusing on the latest data on the medical treatment for OSSN.

\section{METHODS}

A search of the MEDLINE database was performed using the keywords "ocular surface 
squamous neoplasia," "squamous conjunctival carcinoma," and "conjunctival carcinoma in situ." All reports published in English up to May 2018, including those available online ahead of print, were included. As such, this article is based on previously conducted studies and does not contain any studies with human participants or animals performed by any of the authors.

\section{RISK FACTORS AND PATHOGENESIS}

The primary risk factor for OSSN is ultraviolet (UV) B radiation, with people chronically exposed to direct solar light and those involved in outdoor occupations being at the most risk [9]. According to an Australian populationbased study [4], Individuals with fair skin, light iris color and/or susceptible to sunburn, those who spent $>50 \%$ of time outdoors during the first 6 years of life, and those living within $30^{\circ}$ of the equator carry the greatest risk for developing the tumor.

Non-modifiable risk factors include male gender and age [11-13]. A longitudinal study published in the USA in 2018 reported that U.S. men had a 12-fold higher incidence rate than U.S. women and that this rate was stable in a follow-up of 4 years [14]. Conversely, in populations in African countries, OSSN prevalence peaks at a relatively younger age and there is no gender predilection; in addition, the epidemiologic trend is increasing $[15,16]$. Modifiable risk factors are cigarette smoking $[1,11]$, vitamin A or retinol deficiency [17], chronic trauma or inflammation [18], and exposure to petroleum products; more recently, the use of topical voriconazole has been proposed as a predisposing factor $[19,20]$.

Infectious diseases such as human immunodeficiency virus types 1 and 2 (HIV-1 and -2) [21-24], human papillomavirus (HPV) serotypes 16 and 18 [25], and hepatitis B and C virus [26] play a putative role in the pathogenesis of OSSN.

HIV has been associated with a eightfold increased risk of OSSN [27], with the highest rate of incidence in the first 2 years of acquired immunodeficiency syndrome (AIDS) [28]. As OSSN can be the first presenting sign of HIV/ AIDS in $50-86 \%$ of cases [23, 29-32], screening for the presence of the virus should be always performed in atypical cases or in endemic regions. HIV infection has been associated with younger age at presentation of OSSN [31, 33], female or no gender predilection [16, 34, 35], more severe course [36, 37], bilaterality [38], worse prognosis [32], and increased risk of recurrence [39]. Immune dysregulation syndromes other than AIDS, including iatrogenic immunosuppression post-organ transplantation [39], non-Hodgkin's lymphoma [40], asthma/ eczema/atopic diseases [41-44], ocular cicatricial pemphigoid [45], xeroderma pigmentosum [46], and Papillon-Lefèvre syndrome [47], can also predispose to OSSN.

It is thought that the breakdown of the human body's immune surveillance against the tumor creates a "permissive environment" for other risk factors to trigger malignant transformation of the epithelial cells [39]. For example, HPV infection, which is associated with HPVinduced inhibition of the tumor-suppressor protein retinoblastoma $(\mathrm{Rb})$, may interact synergistically with sunlight exposure, which can cause UV radiation-related DNA damage, including the formation of pyrimidine dimers $(\mathrm{CC}>\mathrm{TT})$ and epigenetic changes in the p16 gene promoter [48], and lead to triggering of the neoplastic transformation of the cell lineage.

There is no clear genetic mutation associated with OSSN [49]. However, one of the key events reported are mutations affecting the tumor suppressor gene p53, with a high percentage of CC $>$ TT alterations, which confirms the causative role of solar rays in the etiology of the tumor [50]. Moreover, Scholz et al. identified mutations in the telomerase reverse transcriptase (TERT) gene promoter-a marker of other systemic cancers [51] and a sign of worse prognosis [52, 53] -in $44 \%$ of the 48 samples of conjunctival OSSN included in their study [54]. Finally, hyper-expression of matrix metalloproteinases MMP-9 and MMP-11 and hypo-expression of clusterin seem to be a hallmark in the tumor cell transcriptome [55]. 


\section{CLINICAL PRESENTATION}

The usual presentation of OSSN is a unilateral vascularized limbal mass located in the interpalpebral fissure; it can also present as a bilateral/multifocal mass, albeit rarely [1]. Even more rarely, the tumor can involve the tarsal conjunctiva or it can be associated with pterygia or other benign conditions; both presentations make the correct diagnosis more challenging [56].

According to its morphology, OSSN can be classified into nodular, nodulo-ulcerative [57], gelatinous, leukoplakic, placoid, or papillary forms. The macroscopic appearance is a yellowpink lesion with tortuous dilated feeder vessels, sometimes with keratinized plaques on its surface [58]. In dark-skinned people, the mass is commonly pigmented. HIV-related lesions are often larger, with forniceal extension, and feature more areas of leukoplakia with pronounced feeder vessels $[16,59]$. The tumor may also have a less obvious appearance, such as opalescence on the cornea or chronic conjunctivitis [60], leading to a considerable delay in the correct diagnosis. The most common signs and symptoms are a red eye, ocular irritation, and the appearance of a new mass in the eye; in very advanced cases, necrotizing scleritis, associated with severe pain and visual loss, have been described [37, 61].

At the microscopic level, OSSN presents as a range of cellular dysplasia, from mild, moderate, to severe; distinctly neoplastic cells with an intact basal membrane are characteristic of the carcinoma in situ. When the basal membrane is involved, the tumor acquires features that are characteristic of invasive SCC. Some changes suggestive of this malignant transformation include a diffuse or multifocal configuration [62], brown pigmentation, median basal diameter of $>10 \mathrm{~mm}$, and thickness of $>1 \mathrm{~mm}$ [63].

\section{DIAGNOSIS}

The gold standard for the diagnosis of OSSN remains histopathologic evaluation following an incisional or excisional biopsy [62]. However, in the past three decades, technological innovations have led to the introduction of less or non-invasive methods of diagnosis, including impression cytology [64], in vivo confocal microscopy (IVCM) [65, 66], and high-resolution or ultra-high-resolution anterior segment optical coherence tomography (HR-OCT) [67]. Impression cytology [64] or exfoliative cytology $[68,69]$ are two methods that can be used to identify superficial dysplastic lesions, but they cannot assess the potential invasive growth of these lesions; moreover, they require a dedicated preparation and immediate analysis after tissue sampling.

Examination by IVCM reveals such OSSN features as pleomorphic epithelial cells, hyperreflectivity of the epithelium, demarcation line between normal and neoplastic area, enlarged nuclei with prominent nucleoli in the basal epithelium ("starry sky" appearance), and loss of limbal dendritic cells [65, 66, 70-72]. Similar characteristics are discernible non-invasively using HR-OCT [73, 74]. However, the diagnostic sensibility of this latter imaging modality is dependent on the training level of the users and ranges from 94 to $100 \%$, with a specificity of up to $100 \%[67,75,76]$. HR-OCT also allows for detection of treatment response and subclinical recurrence. The main limitation of HR-OCT is the impossibility to perceive deep invasion of the tumor or the histologic grade. Another diagnostic imaging modality, ultrasound biomicroscopy (UBM), has the considerable advantage of detecting the infiltration of adjacent structures due to its higher penetration and capability to achieve a better resolution of the posterior margin of the lesions [77, 78]. Examination using UBM reveals a hyperechoic tumor surface with a generally hypoechoic tumor stroma; this pattern differs from the hyperechoic orbital tissues, and is easily identifiable in cases of orbital invasion [77]. However, UBM is time-consuming and highly operator-dependent, and requires direct contact with the eye.

Due to the specific drawbacks of non-invasive imaging techniques, histopathology is still fundamental to the early identification of potential corneal, scleral, intraocular or orbital invasion of the tumor. Regional and systemic investigations by ultrasound, computed tomography, or magnetic resonance imaging 
are often necessary for the correct staging and to plan the appropriate treatment (see "Treatment").

\section{TREATMENT}

The management of OSSN includes surgical resection [79] and medical or para-surgical treatments, namely, topical chemotherapy (mitomycin C [MMC], 5-fluorouracil [5-FU]), topical/local immunomodulation with interferon alpha-2b (IFN- $\alpha 2 b$ ), topical antiviral medications (cidofovir) [80, 81], and photodynamic therapy [82]. Treatment with anti-vascular endothelial growth factor has also been tried, with inconsistent results $[83,84]$.

Surgical removal of conjunctival lesions is carried out following the Shields' "no touch" technique to avoid the potential risk of seeding. This technique incorporates large macroscopically tumor-free margins (at least $4 \mathrm{~mm}$ ) in the bioptic piece to increase the likelihood of clear margins [79]. Cryotherapy is then applied to the conjunctival and limbal margins in a "double freeze slow thaw" technique, which achieves the rupture of tumor cell membranes and the occlusion of the blood vessels $[85,86]$.

Corneal components are removed through alcohol keratoepitheliectomy leaving at least 2-mm tumor-free margins [79], while scleral invasion is addressed with partial lamellar sclerectomy [87]. Enucleation or orbital exenteration is reserved for cases with intraocular or periocular invasion, respectively [88, 89]. Extensive surgical excision of limbar OSSN (dissection duration of $\geq 6$ clock-hours) carries the risk of limbal stem cell deficiency (LSCD), while the removal of large conjunctival tissue may lead to scarring and symblepharon, despite the use of cryopreserved amniotic membrane to cover the resulting defect $[90,91]$. LSCD can be prevented with intraoperative limbal epithelial transplantation, which has shown promising results $[92,93]$. Alternatively, to minimize the amount of tissue removed, a modified Mohs technique with intraoperative control of surgical margins has also been suggested [87, 94].
As surgery carries with it undeniable complications, as discussed above, the option of medical therapy has gained increasing popularity in the treatment of OSSN and is considered to be superior to invasive approaches in the treatment of subclinical and microscopic disease [95].

MMC is a potent alkylating agent used topically as a primary treatment [96] or with the adjunction of surgical resection-before (chemoreduction), intraoperatively, or after (chemopreventive) the procedure-to reduce the risk of recurrence [97-104]. Both the regimens of 1 drop of MMC $0.02 \%$ three times daily for at least two 1-week courses [101] and 1 drop of MMC $0.04 \%$ four times daily for at least two 1-week courses [105] have been demonstrated to be effective. The treatment is limited by MMC-related side effects, including photophobia, dry eye, punctal stenosis, persistent epithelial defects, LSCD, and allergic reactions, all of which are very common [106].

5 -FU is a structural analog of thymine and inhibitor of the enzyme thymidylate synthetase. It impairs DNA and RNA synthesis in both normal and tumor cells, but as the amount of nucleic acids synthesis is higher in tumoral cells, the drug has a relative selectivity for the cancerous lineage [107, 108]. 5-FU has been delivered topically as a $1 \% 5$-FU formulation four times/day for 4 weeks [109] or for 1 week followed by a drug holiday of 3 weeks [110], depending on the study. As primary therapy for OSSN, 5-FU has shown an efficacy of $85-100 \%$ [109-111], with a tumor recurrence rate ranging from 1.1 to $43 \%$ [112].

Interferons are natural glycoproteins with antiviral and antimicrobial properties that are released by several types of immune cells secondary to tumors or viral infections $[113,114]$. Their role as antineoplastic agents is due to their anti-proliferative, anti-angiogenic, and cytotoxic effects, as well as to their property of being a potential inducer of the host antitumor immunosurveillance [115]. The first evidence of the efficacy of topical INF in the regression of limbal epithelial dysplasia was published in 1994 [116]. Since then, recombinant human IFN- $\alpha 2 b$ has been used as the primary agent (immunotherapy) for small corneal or 
conjunctival tumors (i.e., basal diameter $<20 \mathrm{~mm}$, extension $<6 \quad$ clock-hours) [117-123], as a neoadjuvant agent (immunoreduction) for diffuse tumor (i.e., basal diameter $>20 \mathrm{~mm}$, extension $>6$ clock-hours) to facilitate surgical excision; [124, 125], and as adjuvant therapy (immunoprevention), in the presence of positive margins after resection [126-129]. According to the most recently published analysis (Table 1), the drug has demonstrated a high rate of resolution, an acceptable rate of recurrence, and minimal toxicity when used in primary immunotherapy [117, 130-132].

IFN- $\alpha 2 b$ is prescribed either topically as drops or locally as perilesional subconjunctival injections [133]. There is as yet no consensus on the dosage of local IFN- $\alpha 2 b$ to be injected, and dosages ranging from 3 million international units (MIU)/0.5 cc [130, 134] upwards to $9 \mathrm{MIU} /$ $0.5 \mathrm{cc}$ [129] or downwards to 3 [125, 126], 5 [120], 10 [127, 135] MIU/cc once a month have been reported. For focal lesions, the entire injection is given in only one location; for multifocal disease, the injection is distributed over all of the involved areas. There is relatively more consensus on the dosage of topical IFN$\alpha 2 \mathrm{~b}$, as it is given at a standard dose of $1 \mathrm{MIU} /$ $\mathrm{mL}$ one drop 4 times/day, even though a dose of $3 \mathrm{MIU} / \mathrm{mL}$ one drop 4 times/day has also been reported, with no difference in efficacy $[72,119,133]$. The vial must be kept refrigerated and is replaced every 2 weeks. Median resolution time ranges from 1.5 to 6 months of treatment [44, 72]. After macroscopic clinical regression, the drug is often continued for additional cycles to prevent recurrences, even though the total length of the treatment varies among the different studies, ranging from 1 to 4 months [10, 72, 120, 136].

Being an endogenous molecule, INF is better tolerated than chemotherapeutic agents. Perilesional injections of IFN- $\alpha 2 b$ are associated with transient flu-like symptoms, while topical drops are associated with irritation, conjunctival hyperemia [129], reactive lymphoid hyperplasia [137], and follicular conjunctivitis [135]; side effects usually resolve with treatment discontinuation. One of the limitations of IFN$\alpha 2 b$ with respect to surgery is the economic burden, even though the availability and affordability of the medical drug has been improving in recent years. A $10-\mathrm{MIU} / \mathrm{mL}$ vial costs $\$ 179-235$ in the USA, for a total of $>\$ 700$ for a 4-month cycle of injective therapy and a total of \$1074-1440 for a 6-month cycle of topical treatment. In other countries outside the USA (e.g., India), the cost-effectiveness of IFN- $\alpha 2 b$ is much more favorable [120].

While an efficient immune system has been advocated as a requisite for IFN- $\alpha 2 b$ efficacy $[138,139]$, the presence of HPV infection does not seem to influence the response to the treatment [140]. In case of HIV-related immunosuppression, clinicians should prefer non-immunomodulating agents, such as 5-FU or MMC, in association with the highly active anti-retroviral therapy (HAART) protocol, even though the role of HAART in OSSN regression is still being debated [37, 141]. Conversely, there are very few studies investigating the prognostic signs able to predict the response to IFN- $\alpha 2 b$. Zarei-Ghanavati and associates found a borderline difference in the number of limbal dendritic cells after 1 month of topical IFN- $\alpha 2 b$ between responders and non-responders, in favor of responders [72]. Invasion of the epithelial basement membrane and the Bowman's layer fo not seem to be a negative prognostic factor [135], while the size of the tumor at baseline has been associated with a longer treatment [142].

Cidofovir is an antiviral agent with activity against double-stranded DNA viruses, including HPV. The antitumor activity of cidofovir, independent of the virus infection status of the patient, is due to the incorporation of the molecule into replicating DNA, where it causes direct DNA damage and promotes cellular apoptosis. A dose of $2.5 \mathrm{mg} / \mathrm{mL}$ topical cidofovir has shown encouraging efficacy as secondary treatment in multi-refractory OSSN [80].

Finally, in selected cases of invasive disease, brachytherapy $[58,143]$ or proton-beam radiotherapy $[144,145]$ can be used in the attempt to salvage the eyeball. 


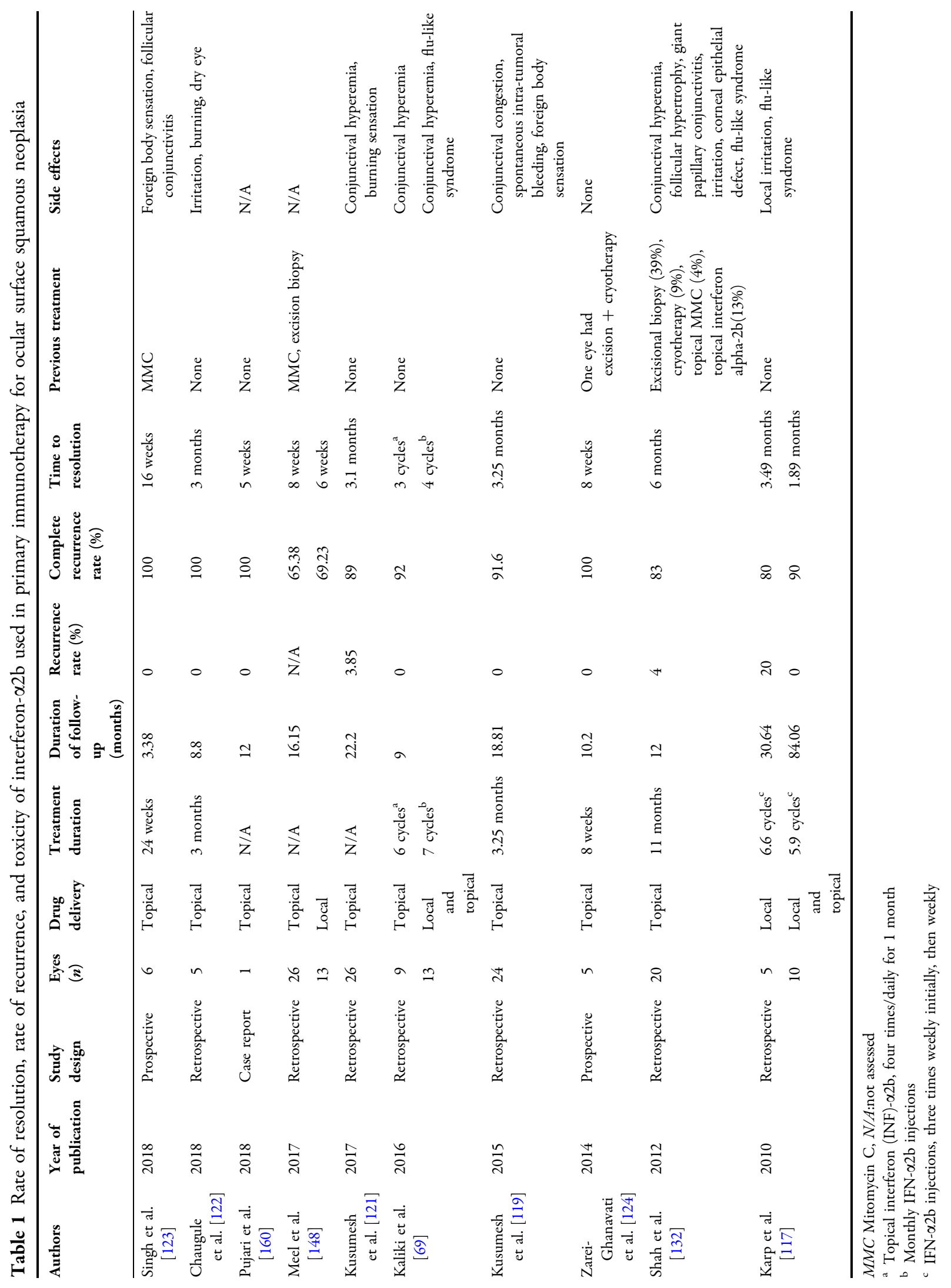


Table 2 Definitions of TNM (Tumor, Node, Metastasis) and histopathologic grade for ocular surface squamous neoplasia, according to the American Joint Committee on Cancer eighth edition cancer staging manual Adapted from [146]

\begin{tabular}{ll}
\hline TNM & Definition \\
staging & \\
\hline
\end{tabular}

Primary tumor (T)

TX Cannot assess the primary tumor

T0 No evidence of primary tumor

Tis Carcinoma in situ

T1 Tumor $(<5 \mathrm{~mm}$ in greatest dimension) invades through the basement membrane without invasion of adjacent structures ${ }^{\mathrm{a}}$

T2 Tumor ( $>5 \mathrm{~mm}$ in greatest dimension) invades through the basement membrane without invasion of adjacent structures ${ }^{\mathrm{a}}$

T3 Tumor invades adjacent structures excluding the orbit

T4 Tumor invades orbit with or without further extension

T4a Tumor invades orbital soft tissues without bone invasion

T4b Tumor invades the bone

T4c Tumor invades adjacent paranasal sinuses

T4d Tumor invades the brain

Lymph node $(\mathrm{N})$

NX Regional lymph nodes cannot be assessed

N0 Regional lymph node metastasis absent

N1 Regional lymph node metastasis present

Systemic metastasis (M)

$\begin{array}{ll}\text { M0 } & \text { No distant metastasis } \\ \text { M1 } & \text { Distant metastasis }\end{array}$

Histopathologic grade $(\mathrm{G})$

\begin{tabular}{ll} 
GX & Grade cannot be assessed \\
G1 & Well differentiated \\
G2 & Moderately differentiated \\
G3 & Poorly differentiated \\
\hline
\end{tabular}

Table 2 continued

\begin{tabular}{ll}
\hline $\begin{array}{l}\text { TNM } \\
\text { staging }\end{array}$ & Definition \\
\hline G4 & Undifferentiated \\
\hline
\end{tabular}

a Adjacent structures in all cases include the cornea, forniceal/palpebral/tarsal conjunctiva, intraocular chambers, caruncle and plica semilunaris, lacrimal puncta and canaliculi, anterior/posterior eyelid lamellae, and eyelid margin

\section{CLASSIFICATION}

Tumor staging is assessed using the TNM (Tumor, Node, Metastasis) definitions, as stated in the American Joint Committee on Cancer (AJCC) recommendations, with $\mathrm{T}$ describing features of the primary tumor, $\mathrm{N}$ describing involvement of the regional nodes, and $\mathrm{M}$ describing the spread of distant metastasis. The eighth edition of the AJCC classification has been recently released, and the definitions for $\mathrm{T} 1$ and T2 differ from those in the seventh edition. In the seventh edition the definition of $\mathrm{T} 1$ and $\mathrm{T} 2$ was based solely on the tumor size, whereas in the eighth edition T classification is based both on the tumor size $(\leq 5$ or $>5 \mathrm{~mm}$ ) and the invasiveness of the basement membrane and adjacent structures, namely the fornix, the plica semilunaris, the caruncle, the eyelid lamellae, the orbit, the sinuses bone, and the brain (Table 2) [146].

Yousef et al. [147] evaluated 101 eyes with OSSN based on the classification of the AJCC seventh edition and reported that the majority of eyes were diagnosed in the Tis and T1 category, with only 1 and $2 \%$ in the T2 and T4 stages, respectively. Similarly, Galor et al. [133] classified 389 OSSN post-excisional cases into T1 (53\%), T2 (36\%), T3 (10\%), and T4 (1\%). To the contrary, more recent statistics based either on the seventh $[135,148]$ or the eighth edition [149] have revealed that only a few lesions presented as in situ, while the majority of the cases fell cumulatively in the T3 or T4 category. This disparity can be explained by the fact that 
Table 3 New clinical classification proposed for ocular surface squamous neoplasia Adapted from [150]

\begin{tabular}{llcl}
\hline Grade & $\begin{array}{l}\text { Limbal involvement } \\
\text { (clock-hours) }\end{array}$ & $\begin{array}{l}\text { Maximal basal } \\
\text { diameter }(\mathbf{m m})\end{array}$ & Treatment \\
\hline Grade I: OSSN with no invasion into ocular coats clinically and on imaging \\
A $\quad \leq 3$ & $\leq 5$ & Surgical excision with margin control \\
$($ small $)$ & & $>5$ to $<15$ & Immunotherapy or immunoreduction \\
B (large) & $>3$ to $<6$ & $\geq 15$ & Immunoreduction \\
C & $\geq 6$ & & \\
(diffuse) &
\end{tabular}

Grade II: OSSN with invasion into ocular coats (sclera/corneal stroma) on imaging ${ }^{a}$
Any
Any
Excision with lamellar sclerectomy or
keratectomy + cryotherapy of margins and base

Grade III: OSSN with intraocular invasion
Any
Any
Enucleation

Grade IV: OSSN with intraorbital extension ${ }^{\mathrm{b}}$
Any
Any
Exenteration

OSSN Ocular surface squamous neoplasia

${ }^{a}$ Imaging in grade I and II relies on ultrasound biomicroscopy

${ }^{b}$ Confirmed by computed tomography or magnetic resonance imaging

OSSN often grows with limbus involvement, shifting the lesion directly to the T3 category, notwithstanding a small dimension. Another limitation of the TNM classification is the inclusion of those lesions with intraocular extension into the T3 category, even though they require enucleation for tumor control, rather than local excision. To overcome these drawbacks of the TNM classification, a new clinical-based classification scheme has been proposed which provides general advice for tumor management (Table 3) [150].

\section{PROGNOSIS}

Overall, OSSN has a good/fair prognosis, with little tendency to metastasize and a low mortality rate; it is often linked to regional or distant metastases or intracranial invasion [151]. However, a recurrence risk of up to $39 \%$ after treatment has been reported in the literature $[2,152-154]$, and this rises to $43 \%$ in cases treated exclusively with surgery or solely with topical agents $[106,107]$. Recurrences take place most frequently within the first 6 months after resection, and the recurrence rate is closely dependent on the involvement of surgical margins [152], the presence of feeder vessels [149], the HIV infection status [33, 155, 156], histopathologic grade [157], and the availability of adjunctive therapies, as such as cryotherapy, immunotherapy or chemotherapy [37]. In terms of the T classification, in 2013, Shields et al. noted that the $\mathrm{T}$ classification, based on the AJCC seventh edition, was not predictive of surgical failure [135]; however, several following reports have correlated the recurrence rate to the $\mathrm{T}$ category, albeit reporting highly heterogeneous groups of patients [147, 149, 158, 159]. Recently, the overexpression of the tumor-suppressor gene $\mathrm{p} 16^{\mathrm{INK4a}}$ has been identified as a biomarker of diffuse growth pattern, early age of presentation $(<50$ years), and metastatization in late $\mathrm{T}$ stages [48]. 


\section{CONCLUSION}

Ocular surface squamous neoplasia is a curable cancer with a low mortality rate, but it remains a considerable medical and economic burden in the peri-equatorial regions of the world. The improvements in non-invasive diagnostic techniques and treatment protocols have led to a considerable reduction in tumor-related morbidity. However, understaging and misdiagnosis of this condition often lead to a preventable loss of vision and the need for more aggressive treatments. HIV infection or predisposing conditions, such as xeroderma pigmentosum or atopic conjunctivitis, should be ruled out in all patients with a diagnosis of OSSN and atypical presentation (i.e., young age, bilateral or multifocal tumors, and history of rapid tumor growth) [24].

Surgical removal with or without cryotherapy is still considered the traditional treatment for OSSN. When there are positive margins or incomplete excision, local or topical IFN- $\alpha 2 b$ represents the best cost-effective approach to minimize tumor recurrence [128]. Nevertheless, primary monotherapy with immunomodulant or chemotherapy agents is now earning increasing recognition and acceptance. Within this framework, systematic reviews and metaanalysis of the recently published literature will help to clarify the efficacy and the limitations of these novel therapeutic approaches to OSSN.

\section{ACKNOWLEDGEMENTS}

Funding. No funding or sponsorship was received for this study or publication of this article.

Authorship. All named authors meet the International Committee of Medical Journal Editors (ICMJE) criteria for authorship for this article, take responsibility for the integrity of the work as a whole, and have given their approval for this version to be published.
Disclosures. Maria Vittoria Cicinelli, Alessandro Marchese, Francesco Bandello and Giulio Modorati have nothing to disclose.

Compliance with Ethics Guidelines. This article is based on previously conducted studies and does not contain any studies with human participants or animals performed by any of the authors.

Data Availability. Data sharing is not applicable to this article as no datasets were generated or analyzed during the current study.

Open Access. This article is distributed under the terms of the Creative Commons Attribution-NonCommercial 4.0 International License (http://creativecommons.org/licenses/ by-nc/4.0/), which permits any noncommercial use, distribution, and reproduction in any medium, provided you give appropriate credit to the original author(s) and the source, provide a link to the Creative Commons license, and indicate if changes were made.

\section{REFERENCES}

1. Lee GA, Hirst LW. Ocular surface squamous neoplasia. Surv Ophthalmol. 1995;39(6):429-50.

2. Shields CL, Chien JL, Surakiatchanukul T, Sioufi K, Lally SE, Shields JA. Conjunctival tumors: review of clinical features, risks, biomarkers, and outcomesthe 2017 J. Donald M. Gass Lecture. Asia Pac J Ophthalmol (Phila). 2017;6(2):109-20.

3. Shields CL, Demirci H, Karatza E, Shields JA. Clinical survey of 1643 melanocytic and nonmelanocytic conjunctival tumors. Ophthalmology. 2004;111(9):1747-54.

4. Lee GA, Hirst LW. Incidence of ocular surface epithelial dysplasia in metropolitan Brisbane. A 10-year survey. Arch Ophthalmol. 1992;110(4):525-7.

5. Sun EC, Fears TR, Goedert JJ. Epidemiology of squamous cell conjunctival cancer. Cancer Epidemiol Biomark Prev. 1997;6(2):73-7.

6. Furahini G, Lewallen S. Epidemiology and management of ocular surface squamous neoplasia in 
Tanzania. Ophthalmic Epidemiol. 2010;17(3):171-6.

7. Emmanuel B, Ruder E, Lin SW, Abnet C, Hollenbeck $\mathrm{A}, \mathrm{Mbulaiteye} \mathrm{S}$. Incidence of squamous-cell carcinoma of the conjunctiva and other eye cancers in the NIH-AARP Diet and Health Study. Ecancermedicalscience. 2012;6:254.

8. Ateenyi-Agaba C. Conjunctival squamous-cell carcinoma associated with HIV infection in Kampala, Uganda. Lancet. 1995;345(8951):695-6.

9. Gichuhi S, Sagoo MS, Weiss HA, Burton MJ. Epidemiology of ocular surface squamous neoplasia in Africa. Trop Med Int Health. 2013;18(12):1424-43.

10. Nanji AA, Moon CS, Galor A, Sein J, Oellers P, Karp CL. Surgical versus medical treatment of ocular surface squamous neoplasia: a comparison of recurrences and complications. Ophthalmology. 2014;121(5):994-1000.

11. Napora C, Cohen EJ, Genvert GI, et al. Factors associated with conjunctival intraepithelial neoplasia: a case control study. Ophthalmic Surg. 1990;21(1):27-30.

12. Lee GA, Hirst LW. Retrospective study of ocular surface squamous neoplasia. Aust N Z J Ophthalmol. 1997;25(4):269-76.

13. Ramberg I, Heegaard S, Prause JU, Sjo NC, Toft PB. Squamous cell dysplasia and carcinoma of the conjunctiva. A nationwide, retrospective, epidemiological study of Danish patients. Acta Ophthalmol. 2015;93(7):663-6.

14. Dalvin LA, Salomao DR, Patel SV. Population-based incidence of conjunctival tumours in Olmsted County, Minnesota. Br J Ophthalmol. 2018. https:// doi.org/10.1136/bjophthalmol-2017-311530.

15. Pola EC, Masanganise R, Rusakaniko S. The trend of ocular surface squamous neoplasia among ocular surface tumour biopsies submitted for histology from Sekuru Kaguvi Eye Unit, Harare between 1996 and 2000. Cent Afr J Med. 2003;49(1-2):1-4.

16. Makupa II, Swai B, Makupa WU, White VA, Lewallen S. Clinical factors associated with malignancy and HIV status in patients with ocular surface squamous neoplasia at Kilimanjaro Christian Medical Centre, Tanzania. $\mathrm{Br} \mathrm{J}$ Ophthalmol. 2012;96(4):482-4.

17. Gichuhi S, Macharia E, Kabiru J, et al. Risk factors for ocular surface squamous neoplasia in Kenya: a case-control study. Trop Med Int Health. 2016;21(12):1522-30.
18. Campanella PC, Goldberg SH, Erlichman K, Abendroth C. Squamous cell tumors and ocular prostheses. Ophthalmic Plast Reconstr Surg. 1998;14(1):45-9.

19. Singh S, Mittal R, Narang P, Mittal V. Ocular surface squamous neoplasia in a setting of fungal keratitis: a rare co-occurrence. Int Ophthalmol. 2018. https:// doi.org/10.1007/s10792-018-0864-8.

20. Palamar M, Egrilmez S, Yilmaz SG, Polat SH, Gunduz OU. Ocular surface squamous neoplasia in a setting of fungal keratitis: a rare co-occurrence. Int Ophthalmol. 2018. https://doi.org/10.1007/s10792018-0933-z.

21. Fogla R, Biswas J, Kumar SK, Madhavan HN, Kumarasamy N, Solomon S. Squamous cell carcinoma of the conjunctiva as initial presenting sign in a patient with acquired immunodeficiency syndrome (AIDS) due to human immunodeficiency virus type-2. Eye (Lond). 2000;14(Pt 2):246-7.

22. Newton R, Ziegler J, Ateenyi-Agaba C, et al. The epidemiology of conjunctival squamous cell carcinoma in Uganda. Br J Cancer. 2002;87(3):301-8.

23. Guech-Ongey M, Engels EA, Goedert JJ, Biggar RJ, Mbulaiteye SM. Elevated risk for squamous cell carcinoma of the conjunctiva among adults with AIDS in the United States. Int $\mathrm{J}$ Cancer. 2008;122(11):2590-3.

24. Rathi SG, Ganguly Kapoor A, Kaliki S. Ocular surface squamous neoplasia in HIV-infected patients: current perspectives. HIV AIDS (Auckl). 2018;10:33-45.

25. Scott IU, Karp CL, Nuovo GJ. Human papillomavirus 16 and 18 expression in conjunctival intraepithelial neoplasia. Ophthalmology. 2002;109(3):542-7.

26. Choi CJ, Jakobiec FA, Zakka FR, Sanchez AV, Lee NG. Ocular surface squamous neoplasia in a patient with hepatitis C. JAMA Ophthalmol. 2017;135(10):1121-3.

27. Carreira H, Coutinho F, Carrilho C, Lunet N. HIV and HPV infections and ocular surface squamous neoplasia: systematic review and meta-analysis. Br J Cancer. 2013;109(7):1981-8.

28. Goedert JJ, Cote TR. Conjunctival malignant disease with AIDS in USA. Lancet. 1995;346(8969):257-8.

29. Karp CL, Scott IU, Chang TS, Pflugfelder SC. Conjunctival intraepithelial neoplasia. A possible marker for human immunodeficiency virus infection? Arch Ophthalmol. 1996;114(3):257-61. 
30. Porges Y, Groisman GM. Prevalence of HIV with conjunctival squamous cell neoplasia in an African provincial hospital. Cornea. 2003;22(1):1-4.

31. Kamal S, Kaliki S, Mishra DK, Batra J, Naik MN. Ocular surface squamous neoplasia in 200 patients: a case-control study of immunosuppression resulting from human immunodeficiency virus versus immunocompetency. Ophthalmology. 2015;122(8): 1688-94.

32. Kaliki S, Kamal S, Fatima S. Ocular surface squamous neoplasia as the initial presenting sign of human immunodeficiency virus infection in 60 Asian Indian patients. Int Ophthalmol. 2016. https://doi.org/10.1007/s10792-016-0387-0.

33. Steele KT, Steenhoff AP, Bisson GP, Nkomazana O. Ocular surface squamous neoplasia among HIV-infected patients in Botswana. S Afr Med J. 2015;105(5):379-83.

34. Chisi SK, Kollmann MK, Karimurio J. Conjunctival squamous cell carcinoma in patients with human immunodeficiency virus infection seen at two hospitals in Kenya. East Afr Med J. 2006;83(5):267-70.

35. Gichuhi S, Macharia E, Kabiru J, et al. Clinical presentation of ocular surface squamous neoplasia in Kenya. JAMA Ophthalmol. 2015;133(11):1305-13.

36. Cackett P, Gillies M, Leen C, Dhillon B. Conjunctival intraepithelial neoplasia in association with HIV infection. AIDS. 2005;19(3):351-2.

37. Gichuhi S, Irlam JH. Interventions for squamous cell carcinoma of the conjunctiva in HIV-infected individuals. Cochrane Database Syst Rev. 2013;2:CD005643.

38. Masanganise R, Mukome A, Dari J, Makunike-Mutasa R. Bilateral HIV related ocular surface squamous neoplasia: a paradigm shift. Cent Afr J Med. 2010;56(5-8):23-6.

39. Shields CL, Ramasubramanian A, Mellen PL, Shields JA. Conjunctival squamous cell carcinoma arising in immunosuppressed patients (organ transplant, human immunodeficiency virus infection). Ophthalmology. 2011;118(11):2133-7.

40. Joshi RS. Ocular surface squamous neoplasia inpatient with non-Hodgkin's lymphoma. Indian J Ophthalmol. 2017;65(1):71-2.

41. Rundle P, Mudhar HS, Rennie I. Conjunctival intraepithelial neoplasia occurring in young patients with asthma. Eye (Lond). 2010;24(7):1182-5.

42. Flynn TH, Manzouri B, Tuft SJ. Ocular surface squamous neoplasia in an immunosuppressed patient with atopic keratoconjunctivitis. Int Ophthalmol. 2012;32(5):471-3.

43. Zhang L, Mercado C, Galor A, Holland EJ, Wang G, Karp CL. Challenging treatment of ocular surface squamous neoplasia in patients with atopic disease. Ocul Immunol Inflamm. 2017. https://doi.org/10. 1080/09273948.2017.1394470.

44. Shah A, Espana EM, Singh AD. Ocular surface squamous neoplasia associated with atopic keratoconjunctivitis. Ocul Oncol Pathol. 2017;3(1):22-7.

45. Choi CJ, Jakobiec FA, Zakka FR, Foster CS, Chodosh J, Freitag SK. Conjunctival squamous cell neoplasia associated with ocular cicatricial pemphigoid. Ophthalmic Plast Reconstr Surg. 2017;33(6):e15760.

46. Agarwal R, Chawla B, Asif MI, Pujari A. Bilateral ocular surface squamous neoplasia with bilateral periocular basal cell carcinoma in a case of xeroderma pigmentosum. BMJ Case Rep. 2017. https:// doi.org/10.1136/bcr-2017-220882.

47. Kaliki S, Singh S, Gowrishankar S, Reddy VAP. Ocular surface squamous neoplasia in Papillon-Lefevre syndrome: outcome at long-term follow-up of 12 years. Cornea. 2017;36(6):743-6.

48. Chauhan S, Sen S, Sharma A, Kashyap S, Tandon R, Bajaj MS, et al. p16(INK4a) overexpression as a predictor of survival in ocular surface squamous neoplasia. Br J Ophthalmol. 2018;102(6):840-7.

49. Gichuhi S, Ohnuma S, Sagoo MS, Burton MJ. Pathophysiology of ocular surface squamous neoplasia. Exp Eye Res. 2014;129:172-82.

50. Ateenyi-Agaba C, Dai M, Le Calvez F, et al. TP53 mutations in squamous-cell carcinomas of the conjunctiva: evidence for UV-induced mutagenesis. Mutagenesis. 2004;19(5):399-401.

51. Hurst CD, Platt FM, Knowles MA. Comprehensive mutation analysis of the TERT promoter in bladder cancer and detection of mutations in voided urine. Eur Urol. 2014;65(2):367-9.

52. Landa I, Ganly I, Chan TA, et al. Frequent somatic TERT promoter mutations in thyroid cancer: higher prevalence in advanced forms of the disease. J Clin Endocrinol Metab. 2013;98(9):E1562-6.

53. Jung SJ, Kim DS, Park WJ, et al. Mutation of the TERT promoter leads to poor prognosis of patients with non-small cell lung cancer. Oncol Lett. 2017;14(2):1609-14.

54. Scholz SL, Thomasen H, Reis H, et al. Frequent TERT promoter mutations in ocular surface squamous 
neoplasia. Invest Ophthalmol Vis Sci. 2015;56(10): 5854-61.

55. Mahale A, Alkatan H, Alwadani S, et al. Altered gene expression in conjunctival squamous cell carcinoma. Mod Pathol. 2016;29(5):452-60.

56. Oellers P, Karp CL, Sheth A, et al. Prevalence, treatment, and outcomes of coexistent ocular surface squamous neoplasia and pterygium. Ophthalmology. 2013;120(3):445-50.

57. Kaliki S, Freitag SK, Chodosh J. Nodulo-ulcerative ocular surface squamous neoplasia in 6 patients: a rare presentation. Cornea. 2017;36(3):322-6.

58. Arepalli S, Kaliki S, Shields CL, Emrich J, Komarnicky L, Shields JA. Plaque radiotherapy in the management of scleral-invasive conjunctival squamous cell carcinoma: an analysis of 15 eyes. JAMA Ophthalmol. 2014;132(6):691-6.

59. Kabra RC, Khaitan IA. Comparative analysis of clinical factors associated with ocular surface squamous neoplasia in HIV infected and non HIV patients. J Clin Diagn Res. 2015;9(5):NC01-3.

60. Moshirfar M, Khalifa YM, Kuo A, Davis D, Mamalis N. Ocular surface squamous neoplasia masquerading as superior limbic keratoconjunctivitis. Middle East Afr J Ophthalmol. 2011;18(1):74-6.

61. Kim RY, Seiff SR, Howes EL Jr, O'Donnell JJ. Necrotizing scleritis secondary to conjunctival squamous cell carcinoma in acquired immunodeficiency syndrome. Am J Ophthalmol. 1990;109(2): 231-3.

62. Kao AA, Galor A, Karp CL, Abdelaziz A, Feuer WJ, Dubovy SR. Clinicopathologic correlation of ocular surface squamous neoplasms at Bascom Palmer Eye Institute: 2001 to 2010. Ophthalmology. 2012;119(9): 1773-6.

63. Shields CL, Alset AE, Boal NS, et al. Conjunctival tumors in 5002 cases. Comparative analysis of benign versus malignant counterparts. The 2016 James D. Allen Lecture. Am J Ophthalmol. 2017;173:106-33.

64. Barros JD, Lowen MS, Moraes-Filho MN, Martins MC. Use of impression cytology for the detection of unsuspected ocular surface squamous neoplasia cells in pterygia. Arq Bras Oftalmol. 2014;77(5): 305-9.

65. Xu Y, Zhou Z, Xu Y, et al. The clinical value of in vivo confocal microscopy for diagnosis of ocular surface squamous neoplasia. Eye (Lond). 2012;26(6):781-7.
66. Nguena MB, van den Tweel JG, Makupa W, et al. Diagnosing ocular surface squamous neoplasia in East Africa: case-control study of clinical and in vivo confocal microscopy assessment. Ophthalmology. 2014;121(2):484-91.

67. Kieval JZ, Karp CL, Abou Shousha M, et al. Ultrahigh resolution optical coherence tomography for differentiation of ocular surface squamous neoplasia and pterygia. Ophthalmology. 2012;119(3): 481-6.

68. Semenova EA, Milman T, Finger PT, et al. The diagnostic value of exfoliative cytology vs histopathology for ocular surface squamous neoplasia. Am J Ophthalmol. 2009;148(5):772-8.

69. Kayat KV, Correa Dantas PE, Felberg S, Galvao MA, Saieg MA. Exfoliative cytology in the diagnosis of ocular surface squamous neoplasms. Cornea. 2017;36(1):127-30.

70. Malandrini A, Martone G, Traversi C, Caporossi A. In vivo confocal microscopy in a patient with recurrent conjunctival intraepithelial neoplasia. Acta Ophthalmol. 2008;86(6):690-1.

71. Alomar TS, Nubile M, Lowe J, Dua HS. Corneal intraepithelial neoplasia: in vivo confocal microscopic study with histopathologic correlation. Am J Ophthalmol. 2011;151(2):238-47.

72. Zarei-Ghanavati M, Mousavi E, Nabavi A, et al. Changes in in vivo confocal microscopic findings of ocular surface squamous neoplasia during treatment with topical interferon alfa-2b. Ocul Surf. 2018;16(2):235-41.

73. Thomas BJ, Galor A, Nanji AA, et al. Ultra highresolution anterior segment optical coherence tomography in the diagnosis and management of ocular surface squamous neoplasia. Ocul Surf. 2014;12(1):46-58.

74. Atallah M, Joag M, Galor A, et al. Role of high resolution optical coherence tomography in diagnosing ocular surface squamous neoplasia with coexisting ocular surface diseases. Ocul Surf. 2017;15(4):688-95.

75. Nanji AA, Sayyad FE, Galor A, Dubovy S, Karp CL. High-resolution optical coherence tomography as an adjunctive tool in the diagnosis of corneal and conjunctival pathology. Ocul Surf. 2015;13(3): 226-35.

76. Yim M, Galor A, Nanji A, et al. Ability of novice clinicians to interpret high-resolution optical coherence tomography for ocular surface lesions. Can J Ophthalmol. 2018;53(2):150-4. 
77. Finger PT, Tran HV, Turbin RE, et al. High-frequency ultrasonographic evaluation of conjunctival intraepithelial neoplasia and squamous cell carcinoma. Arch Ophthalmol. 2003;121(2):168-72.

78. Char DH, Kundert G, Bove R, Crawford JB. $20 \mathrm{MHz}$ high frequency ultrasound assessment of scleral and intraocular conjunctival squamous cell carcinoma. Br J Ophthalmol. 2002;86(6):632-5.

79. Shields JA, Shields CL, De Potter P. Surgical management of conjunctival tumors. The 1994 Lynn B. McMahan Lecture. Arch Ophthalmol. 1997;115(6): 808-15.

80. Ip MH, Coroneo MT. Treatment of previously refractory ocular surface squamous neoplasia with topical Cidofovir. JAMA Ophthalmol. 2017;135(5): $500-2$.

81. Ip MH, Robert George CR, Naing Z, Perlman EM, Rawlinson W, Coroneo MT. Topical Cidofovir for treatment-refractory ocular surface squamous neoplasia. Ophthalmology. 2018;125(4):617-9.

82. Cekic O, Bardak Y, Kapucuoglu N. Photodynamic therapy for conjunctival ocular surface squamous neoplasia. J Ocul Pharmacol Ther. 2011;27(2): 205-7.

83. Finger PT, Chin KJ. Refractory squamous cell carcinoma of the conjunctiva treated with subconjunctival ranibizumab (Lucentis): a two-year study. Ophthalmic Plast Reconstr Surg. 2012;28(2):85-9.

84. Asena L, Dursun Altinors D. Topical bevacizumab for the treatment of ocular surface squamous neoplasia. J Ocul Pharmacol Ther. 2015;31(8):487-90.

85. Peksayar G, Soyturk MK, Demiryont M. Long-term results of cryotherapy on malignant epithelial tumors of the conjunctiva. Am J Ophthalmol. $1989 ; 107(4): 337-40$.

86. Sarici AM, Arvas S, Pazarli H. Combined excision, cryotherapy, and intraoperative mitomycin $\mathrm{C}$ (EXCRIM) for localized intraepithelial and squamous cell carcinoma of the conjunctiva. Graefes Arch Clin Exp Ophthalmol. 2013;251(9):2201-4.

87. Buus DR, Tse DT, Folberg R, Buuns DR. Microscopically controlled excision of conjunctival squamous cell carcinoma. Am J Ophthalmol. 1994;117(1): 97-102.

88. Shields JA, Shields CL, Gunduz K, Eagle RC Jr. The 1998 Pan American Lecture. Intraocular invasion of conjunctival squamous cell carcinoma in five patients. Ophthalmic Plast Reconstr Surg. 1999;15(3):153-60.
89. Rajabi MT, Ghasemi H, Safizadeh M, et al. Conjunctival squamous cell carcinoma with intraocular invasion after radiotherapy in epidermodysplasia verruciformis. Can J Ophthalmol. 2014;49(2):e43-6.

90. Hanada K, Nishikawa N, Miyokawa N, Yoshida A. Long-term outcome of amniotic membrane transplantation combined with mitomycin C for conjunctival reconstruction after ocular surface squamous neoplasia excision. Int Ophthalmol. 2017;37(1):71-8.

91. Xie HT, Zhang YY, Jiang DL, Wu J, Wang JS, Zhang MC. Amniotic membrane transplantation with topical interferon alfa-2b after excision of ocular surface squamous neoplasia. Int J Ophthalmol. 2018;11(1):160-2.

92. Kaliki S, Mohammad FA, Tahiliani P, Sangwan VS. Concomitant simple limbal epithelial transplantation after surgical excision of ocular surface squamous neoplasia. Am J Ophthalmol. 2017;174:68-75.

93. Mittal V, Narang P, Menon V, Mittal R, Honavar S. Primary simple limbal epithelial transplantation along with excisional biopsy in the management of extensive ocular surface squamous neoplasia. Cornea. 2016;35(12):1650-2.

94. Tunc M, Char DH, Crawford B, Miller T. Intraepithelial and invasive squamous cell carcinoma of the conjunctiva: analysis of 60 cases. Br J Ophthalmol. 1999;83(1):98-103.

95. Adler E, Turner JR, Stone DU. Ocular surface squamous neoplasia: a survey of changes in the standard of care from 2003 to 2012. Cornea. 2013;32(12):1558-61.

96. Hirst LW. Randomized controlled trial of topical mitomycin C for ocular surface squamous neoplasia: early resolution. Ophthalmology. 2007;114(5):976-82.

97. Chen C, Louis D, Dodd T, Muecke J. Mitomycin C as an adjunct in the treatment of localised ocular surface squamous neoplasia. Br J Ophthalmol. 2004;88(1):17-8.

98. Rahimi F, Alipour F, Ghazizadeh Hashemi H, Hashemian MN, Mehrdad R. Topical mitomycin-C for treatment of partially-excised ocular surface squamous neoplasia. Arch Iran Med. 2009;12(1):55-9.

99. Gupta A, Muecke J. Treatment of ocular surface squamous neoplasia with Mitomycin C. Br J Ophthalmol. 2010;94(5):555-8. 
100. Russell HC, Chadha V, Lockington D, Kemp EG. Topical mitomycin $\mathrm{C}$ chemotherapy in the management of ocular surface neoplasia: a 10-year review of treatment outcomes and complications. Br J Ophthalmol. 2010;94(10):1316-21.

101. Birkholz ES, Goins KM, Sutphin JE, Kitzmann AS, Wagoner MD. Treatment of ocular surface squamous cell intraepithelial neoplasia with and without mitomycin C. Cornea. 2011;30(1):37-41.

102. Besley J, Pappalardo J, Lee GA, Hirst LW, Vincent SJ. Risk factors for ocular surface squamous neoplasia recurrence after treatment with topical mitomycin $\mathrm{C}$ and interferon alpha-2b. Am J Ophthalmol. 2014;157(2):287-93.

103. Kalamkar C, Radke N, Mukherjee A, Radke S. Topical mitomycin-C chemotherapy in ocular surface squamous neoplasia. J Clin Diagn Res. 2016;10(9):NJ01.

104. Singh S, Mittal R, Rath S. Multifocal ocular surface squamous neoplasia. Ophthalmic Plast Reconstr Surg. 2017;33(6):e156-7.

105. Wilson MW, Hungerford JL, George SM, Madreperla SA. Topical mitomycin $\mathrm{C}$ for the treatment of conjunctival and corneal epithelial dysplasia and neoplasia. Am J Ophthalmol. 1997;124(3):303-11.

106. Frucht-Pery J, Sugar J, Baum J, Sutphin JE, Pe'er J, Savir H, et al. Mitomycin C treatment for conjunctival-corneal intraepithelial neoplasia: a multicenter experience. 1997;104(12):2085-93.

Ophthalmology.

107. Midena E, Angeli CD, Valenti M, de Belvis V, Boccato P. Treatment of conjunctival squamous cell carcinoma with topical 5-fluorouracil. Br J Ophthalmol. 2000;84(3):268-72.

108. Gichuhi S, Macharia E, Kabiru J, et al. Topical fluorouracil after surgery for ocular surface squamous neoplasia in Kenya: a randomised, double-blind, placebo-controlled trial. Lancet Glob Health. 2016;4(6):e378-85.

109. Parrozzani R, Lazzarini D, Alemany-Rubio E, Urban F, Midena E. Topical 1\% 5-fluorouracil in ocular surface squamous neoplasia: a long-term safety study. Br J Ophthalmol. 2011;95(3):355-9.

110. Joag MG, Sise A, Murillo JC, et al. Topical 5-fluorouracil $1 \%$ as primary treatment for ocular surface squamous neoplasia. Ophthalmology. 2016;123(7):1442-8.

111. Parrozzani R, Frizziero L, Trainiti S, et al. Topical 1\% 5-fluoruracil as a sole treatment of corneoconjunctival ocular surface squamous neoplasia: long-term study. Br J Ophthalmol. 2017;101(8):1094-9.
112. Bahrami B, Greenwell T, Muecke JS. Long-term outcomes after adjunctive topical 5-flurouracil or mitomycin $\mathrm{C}$ for the treatment of surgically excised, localized ocular surface squamous neoplasia. Clin Exp Ophthalmol. 2014;42(4):317-22.

113. Parmar S, Platanias LC. Interferons: mechanisms of action and clinical applications. Curr Opin Oncol. 2003;15(6):431-9.

114. Gonzalez-Navajas JM, Lee J, David M, Raz E. Immunomodulatory functions of type I interferons. Nat Rev Immunol. 2012;12(2):125-35.

115. Bracarda S, Eggermont AM, Samuelsson J. Redefining the role of interferon in the treatment of malignant diseases. Eur J Cancer. 2010;46(2):284-97.

116. Maskin SL. Regression of limbal epithelial dysplasia with topical interferon. Arch Ophthalmol. 1994;112(9):1145-6.

117. Karp CL, Galor A, Chhabra S, Barnes SD, Alfonso EC. Subconjunctival/perilesional recombinant interferon alpha2b for ocular surface squamous neoplasia: a 10-year review. Ophthalmology. 2010;117(12):2241-6.

118. Krilis M, Tsang H, Coroneo M. Treatment of conjunctival and corneal epithelial neoplasia with retinoic acid and topical interferon alfa-2b: longterm follow-up. Ophthalmology. 2012;119(10):1969-73.

119. Kusumesh R, Ambastha A, Sinha B, Kumar R. Topical interferon alpha-2b as a single therapy for primary ocular surface squamous neoplasia. Asia Pac J Ophthalmol (Phila). 2015;4(5):279-82.

120. Kaliki S, Singh S, Iram S, Tripuraneni D. Recombinant interferon alpha $2 \mathrm{~b}$ for ocular surface squamous neoplasia: an efficient and cost-effective treatment modality in Asian Indian patients. Indian J Ophthalmol. 2016;64(10):702-9.

121. Kusumesh R, Ambastha A, Kumar S, Sinha BP, Imam $\mathrm{N}$. Retrospective comparative study of topical interferon alpha2b versus mitomycin $\mathrm{C}$ for primary ocular surface squamous neoplasia. Cornea. 2017;36(3):327-31.

122. Chaugule SS, Park J, Finger PT. Topical chemotherapy for giant ocular surface squamous neoplasia of the conjunctiva and cornea: is surgery necessary? Indian J Ophthalmol. 2018;66(1):55-60.

123. Singh M, Gautam N, Kaur M. Role of topical interferon alpha-2b in 'mitomycin-C-resistant' ocular surface squamous neoplasia: our preliminary findings. Int Ophthalmol. 2018. https://doi.org/10. 1007/s10792-017-0811-0. 
124. Zarei-Ghanavati S, Alizadeh R, Deng SX. Topical interferon alpha-2b for treatment of noninvasive ocular surface squamous neoplasia with 360 degrees limbal involvement. J Ophthalmic Vis Res. 2014;9(4):423-6.

125. Kim SE, Salvi SM. Immunoreduction of ocular surface tumours with intralesional interferon alpha-2a. Eye (Lond). 2018;32(2):460-2.

126. Nemet AY, Sharma V, Benger R. Interferon alpha $2 b$ treatment for residual ocular surface squamous neoplasia unresponsive to excision, cryotherapy and mitomycin-C. Clin Exp Ophthalmol. 2006;34(4):375-7.

127. Rishi P, Shields CL. Intralesional and topical interferon therapy following incomplete primary excision of ocular surface squamous neoplasia. Indian J Ophthalmol. 2016;64(6):460-1.

128. Siedlecki AN, Tapp S, Tosteson AN, Larson RJ, Karp $\mathrm{CL}$, Lietman $\mathrm{T}$, et al. Surgery versus interferon alpha-2b treatment strategies for ocular surface squamous neoplasia: a literature-based decision analysis. Cornea. 2016;35(5):613-8.

129. Antonietta Blasi M, Maceroni M, Grazia Sammarco M, Pagliara MM. Mitomycin C or interferon as adjuvant therapy to surgery for ocular surface squamous neoplasia: comparative study. Eur J Ophthalmol. 2018;28(2):204-9.

130. Vann RR, Karp CL. Perilesional and topical interferon alfa-2b for conjunctival and corneal neoplasia. Ophthalmology. 1999;106(1):91-7.

131. Boehm MD, Huang AJ. Treatment of recurrent corneal and conjunctival intraepithelial neoplasia with topical interferon alfa 2b. Ophthalmology. 2004;111(9):1755-61.

132. Shah SU, Kaliki S, Kim HJ, Lally SE, Shields JA, Shields CL. Topical interferon alfa-2b for management of ocular surface squamous neoplasia in 23 cases: outcomes based on American Joint Committee on Cancer classification. Arch Ophthalmol. 2012;130(2):159-64.

133. Galor A, Karp CL, Chhabra S, Barnes S, Alfonso EC. Topical interferon alpha $2 \mathrm{~b}$ eye-drops for treatment of ocular surface squamous neoplasia: a dose comparison study. Br J Ophthalmol. 2010;94(5):551-4.

134. Moon CS, Nanji AA, Galor A, McCollister KE, Karp CL. Surgical versus medical treatment of ocular surface squamous neoplasia: a cost comparison. Ophthalmology. 2016;123(3):497-504.

135. Shields CL, Kaliki S, Kim HJ, et al. Interferon for ocular surface squamous neoplasia in 81 cases: outcomes based on the American Joint Committee on Cancer classification. Cornea. 2013;32(3):248-56.

136. Schechter BA, Schrier A, Nagler RS, Smith EF, Velasquez GE. Regression of presumed primary conjunctival and corneal intraepithelial neoplasia with topical interferon alpha-2b. Cornea. 2002;21(1):6-11.

137. Lee GA, Hess L, Glasson WJ, Whitehead K. Topical interferon alpha-2b induced reactive lymphoid hyperplasia masquerading as orbital extension of ocular surface squamous neoplasia. Cornea. 2018;37(6):796-8.

138. Mata E, Conesa E, Castro M, Martinez L, de Pablo C, Gonzalez ML. Conjunctival squamous cell carcinoma: paradoxical response to interferon eyedrops. Arch Soc Esp Oftalmol. 2014;89(7):293-6.

139. Ashkenazy N, Karp CL, Wang G, Acosta CM, Galor A. Immunosuppression as a possible risk factor for interferon nonresponse in ocular surface squamous neoplasia. Cornea. 2017;36(4):506-10.

140. Galor A, Garg N, Nanji A, et al. Human Papilloma virus infection does not predict response to interferon therapy in ocular surface squamous neoplasia. Ophthalmology. 2015;122(11):2210-5.

141. Holkar S, Mudhar HS, Jain A, et al. Regression of invasive conjunctival squamous carcinoma in an HIV-positive patient on antiretroviral therapy. Int J STD AIDS. 2005;16(12):782-3.

142. de Escalona Munoz, Rojas JE, Garcia Serrano JL, Cantero Hinojosa J, Padilla Torres JF, Bellido Munoz RM. Application of interferon alpha $2 \mathrm{~b}$ in conjunctival intraepithelial neoplasia: predictors and prognostic factors. J Ocul Pharmacol Ther. 2014;30(6):489-94.

143. Walsh-Conway N, Conway RM. Plaque brachytherapy for the management of ocular surface malignancies with corneoscleral invasion. Clin Exp Ophthalmol. 2009;37(6):577-83.

144. Ramonas KM, Conway RM, Daftari IK, Crawford JB, O'Brien JM. Successful treatment of intraocularly invasive conjunctival squamous cell carcinoma with proton beam therapy. Arch Ophthalmol. 2006;124(1):126-8.

145. Murthy R, Gupta H, Krishnatry R, Laskar S. Electron beam radiotherapy for the management of recurrent extensive ocular surface squamous neoplasia with orbital extension. Indian J Ophthalmol. 2015;63(8):672-4.

146. Conway RM, Graue GF, Pelayes DE. Conjunctival carcinoma. AJCC cancer staging manual. 8th ed. Basel: Springer; 2017. p. 787-93. 
147. Yousef YA, Finger PT. Squamous carcinoma and dysplasia of the conjunctiva and cornea: an analysis of 101 cases. Ophthalmology. 2012;119(2):233-40.

148. Meel R, Dhiman R, Vanathi M, Pushker N, Tandon $\mathrm{R}$, Devi S. Clinicodemographic profile and treatment outcome in patients of ocular surface squamous neoplasia. Indian J Ophthalmol. 2017;65(10):936-41.

149. Singh S, Mohamed A, Kaliki S. Ocular surface squamous neoplasia: analysis based on the 8th American Joint Committee on Cancer classification. Int Ophthalmol. 2018. https://doi.org/10.1007/ s10792-018-0943-x.

150. Meel R, Dhiman R. Proposal for a new classification for ocular surface squamous neoplasia. Eye (Lond). 2018;32:1284-5.

151. Tabbara KF, Kersten R, Daouk N, Blodi FC. Metastatic squamous cell carcinoma of the conjunctiva. Ophthalmology. 1988;95(3):318-21.

152. Tabin G, Levin S, Snibson G, Loughnan M, Taylor $\mathrm{H}$. Late recurrences and the necessity for long-term follow-up in corneal and conjunctival intraepithelial neoplasia. Ophthalmology. 1997;104(3):485-92.

153. McKelvie PA, Daniell M, McNab A, Loughnan M, Santamaria JD. Squamous cell carcinoma of the conjunctiva: a series of 26 cases. Br J Ophthalmol. 2002;86(2):168-73.

154. Cervantes G, Rodriguez AA Jr, Leal AG. Squamous cell carcinoma of the conjunctiva: clinicopathological features in 287 cases. Can J Ophthalmol. 2002;37(1):14-9 (Discussion 19-20).

155. Spitzer MS, Batumba NH, Chirambo T, Bartz-Schmidt KU, Kayange P, Kalua K, et al. Ocular surface squamous neoplasia as the first apparent manifestation of HIV infection in Malawi. Clin Exp Ophthalmol. 2008;36(5):422-5.

156. Pradeep TG, Gangasagara SB, Subbaramaiah GB, Suresh MB, Gangashettappa N, Durgappa R. Prevalence of undiagnosed HIV infection in patients with ocular surface squamous neoplasia in a tertiary center in Karnataka, South India. Cornea. 2012;31(11):1282-4.

157. Mittal R, Rath S, Vemuganti GK. Ocular surface squamous neoplasia-review of etio-pathogenesis and an update on clinico-pathological diagnosis. Saudi J Ophthalmol. 2013;27(3):177-86.

158. Galor A, Karp CL, Oellers P, et al. Predictors of ocular surface squamous neoplasia recurrence after excisional surgery. Ophthalmology. 2012;119(10):1974-81.

159. Chauhan S, Sen S, Sharma A, et al. American Joint Committee on Cancer Staging and clinicopathological high-risk predictors of ocular surface squamous neoplasia: a study from a tertiary eye center in India. Arch Pathol Lab Med. 2014;138(11):1488-94.

160. Pujari A. Ocular surface squamous neoplasia treated with topical interferon alpha 2b. BMJ Case Rep. 2017;2017:2016218344. 